\title{
Choice of commutation device and development of the scheme of a universal sectionalizing point with automatic load transfer function for the $0.38 \mathrm{kV}$ electric network
}

\author{
A. V. Vinogradov ${ }^{1, *}, A . V$. Vinogradova $^{1}, M . O . \mathrm{Ward}^{2}, A . N . \mathrm{Kharkhardin}^{3}, A . I$. Psaryov ${ }^{3}$, and T. I. Afanasyeva ${ }^{4}$ \\ ${ }^{1}$ Federal Scientific Agroengineering Center VIM, Moscow, Russia \\ ${ }^{2}$ Damascus University, Damascus, Syria \\ ${ }^{3}$ Orel State Agrarian University, Orel, Russia \\ ${ }^{4}$ Kazan State Power Engineering University, Kazan, Russia
}

\begin{abstract}
The overestimated length of rural power lines of $0.38 \mathrm{kV}$ leads to the fact that it is often not possible to fulfill both the sensitivity conditions of the protective device installed at the transformer substation and protecting the line from overloads and short circuits, and the requirements of the power supply reliability of consumers. This problem can be solved by installing in-line universal sectionalizing point equipped with an automatic load transfer function. The use of these devices allows dividing a line into sections provides the necessary sensitivity of protection for each section of the line and the possibility of supplying power to undamaged areas from a backup power source. In addition, only with the use of automated switching devices installed in power lines, it is possible to create intelligent electrical networks. When developing these devices, it is necessary to take into account the electromechanical characteristics of switching devices that are planned to be used for switching lines.
\end{abstract}

\section{Introduction}

The universal sectionalizing point (SP) equipped with an automatic load transfer (ALT) function, microcontroller control unit of the pole-mounted version (SPALT(PM)) is a device designed to perform the functions of sectionalizing and redundancy in $0.38 \mathrm{kV}$ electrical networks. This device allows dividing the $0.38 \mathrm{kV}$ power line into sections and supply power to undamaged areas from a backup power source via the ATS function [1-4]. For such devices, it is important to choose the right switching device in terms of its electromechanical characteristics. First of all, this device should be controlled remotely, must provide the ability to switch short-circuit currents and perform switching at high speed, must have high switching durability.

\section{Switching devices selection}

Vacuum contactors and modular circuit breakers can be considered as sectionalizing devices of the sectioning point for automatic load transfer.

Shunt release devices are used to provide remote control from the operator console in ALT circuit with automatic switches. It is possible to remotely disable both single-phase and three-phase circuit breakers with their help. It is sufficient to apply a voltage pulse to its coil using a communication channel to actuate a shunt release device [5-9].
At the moment, a large range of products from both domestic and foreign manufacturers is presented in the world market. The most famous and reputable companies are: IEK, ABB and Schneider Electric [10].

Table 1 presents the main characteristics of shunt release devices above the specified companies.

Thus, it can be concluded that shunt release devices and circuit breakers manufactured by the above companies have almost similar characteristics. However, the use of the GVAS225 series shunt release device in conjunction with GV2ME or GV2P series automatic switches is the most promising.

The second version of the switching device is a vacuum contactor, for example, LSM/TEL-1-4/400 developed by the company Tavrida Electric. The LSM/TEL-1-4/400 low-voltage vacuum contactor is designed for switching electrical circuits in three-phase alternating current networks of industrial frequency with nominal voltage depending on the performance up to $1140 \mathrm{~V}$. The contactor is able to turn on, conduct and disconnect the currents under normal conditions and at working overloads. It is used in the composition of complete devices as a complete product for frequent switching [14].

The advantages of this device are: large mechanical and switching resource; self-control of control circuits and temperature control unit; insensitivity to voltage dips in auxiliary circuits.

Detailed technical characteristics of the vacuum contactor can be viewed in table 2 .

\footnotetext{
* Corresponding author: vadimbolshev@gmail.com
} 
Table 1. Main characteristics of the shunt release devices [11-13].

\begin{tabular}{|c|c|c|c|}
\hline $\begin{array}{c}\text { Technical } \\
\text { specifications }\end{array}$ & IEK PH-47 & ABB S2C-A & Schneider Electric GVAS225 \\
\hline Rated operating voltage & $230 \mathrm{~V}$ & $230 \mathrm{~V}$ & $230 \mathrm{~V}$ \\
\hline Operating temperature range & From -40 to $+50{ }^{\circ} \mathrm{C}$ & From -40 to $+50^{\circ} \mathrm{C}$ & From -40 to $+50^{\circ} \mathrm{C}$ \\
\hline Operating voltage range & $161-253 \mathrm{~V}$ & $\begin{array}{c}110-415 \mathrm{~V}(\mathrm{AC}) \\
110-220 \mathrm{~V}(\mathrm{DC})\end{array}$ & $-240 \mathrm{~V}$ \\
\hline Pulse power consumption & $3 \mathrm{~W}$ & $-6 \mathrm{~W}$ \\
\hline $\begin{array}{c}\text { Mechanical wear resistance } \\
\text { Degree of protection }\end{array}$ & $>10000 \mathrm{cycles}$ & $>10000$ cycles & $\begin{array}{c}10000 \text { cycles with GV3P and } \\
\text { GV } 30000 \text { cycles with } \\
\text { GV2ME and GV2P }\end{array}$ \\
\hline $\begin{array}{c}\text { Compatibility } \\
\text { with automatic switch }\end{array}$ & BA47-29/100 & S200, M200, DS200 & IPV2L, GV2ME, GV2P, GV3L \\
\hline
\end{tabular}

Table 2. LSM / TEL-1-4 / 400-352 Specifications.

\begin{tabular}{|l|c|}
\hline \multicolumn{1}{|c|}{ Parameter name } & Value \\
\hline Rated voltage, V & 380 \\
\hline Nominal switching and breaking capacity, kA & 4.0 \\
\hline Rated short-time current, 10 s, kA & 3.2 \\
\hline Mechanical resource cycles & Not less than 2 000 000 \\
\hline Maximum number of operations per hour & 500 \\
\hline Switching resource when rated current off, cycles & Not less than 50 \\
\hline On time, ms & Not less than 80 \\
\hline Off time, ms & 220 \\
\hline Rated activation control voltage, V & 176 \\
\hline Minimum voltage perceived as an "ENABLE" command, V & Not less than 10 \\
\hline Preparation time for switching-on: & Not less than 5.5 \\
\hline - after energizing the operating power supply, s & IP40 \\
\hline - after the previous shutdown operation, s & 25 \\
\hline Degree of protection & Not more than 10 \\
\hline Service life, years & \\
\hline
\end{tabular}

Comparison of the characteristics of automatic circuit breaker control devices and a vacuum contactor allows to conclude that it is preferable to use a vacuum contactor as the switching device in the SPALT(PM) since it has the best characteristics in terms of mechanical life, switching on and off and it is more convenient to implement control algorithms.

\section{Development of the SPALT(PM) scheme}

Algorithm SPALT(PM) should allow the use of the device in the modes sectionalizing point and ALT point. Accordingly, the design of the device should allow to perform these algorithms.

An electrical schematic diagram for the universal sectionalizing point with the ALT function and with the microcontroller control unit of the pole-mounted version
(SPALT(PM) has been developed. The diagram is shown in Figure 1.

In the developed scheme, QS1 and QS2 disconnectors are used for manual switching before and after the KM1 vacuum contactor. This contactor is designed for automated switching of the power circuit in all provided modes of operation. The QS3 throw-over switch serves for shunting SP when it is taken out for repair, for technical maintenance. This allows to eliminate the undersupply of electricity to consumers during the SP maintenance. The switch SA1 is used to switch the manual and remote-control mode of the device. A programmable logic controller is used as the control head unit, which receives data on the electrical parameters of the network (current, voltage, frequency and power) through the measurement module and transmits commands to the control unit of the contactor (via the analog output module). Button SB1 "Stop" is used to manually turn off the $0.38 \mathrm{kV} \mathrm{SPALT}(\mathrm{PM})$. It is 


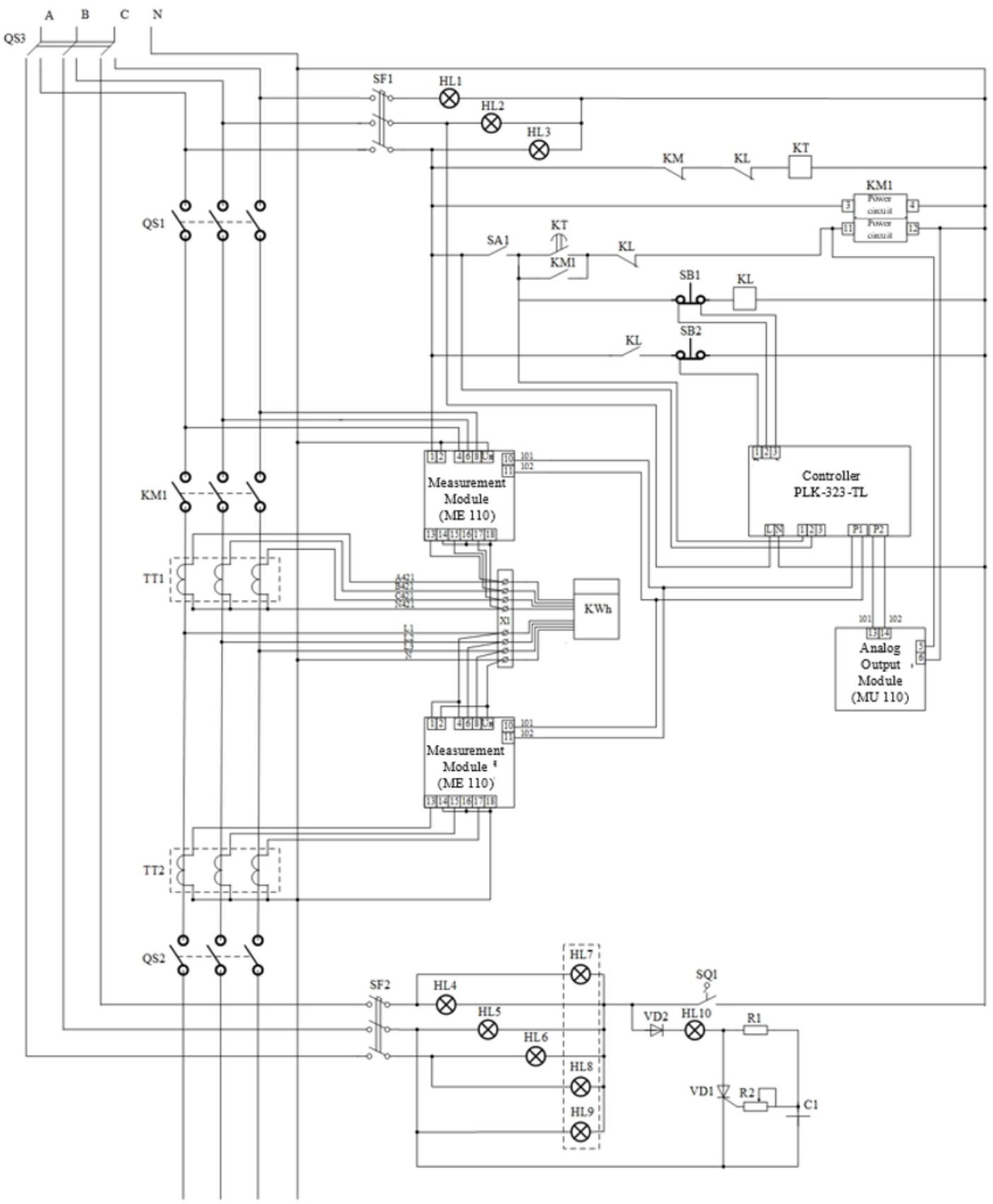

Fig. 1. Electrical schematic diagram of SPALT(PM).

also possible to turn off the device manually by turning off the QS 1 switch. This shutdown is possible only if there is no current flowing through the SPALT(PM). The SB2 "Start" button is designed to restore the initial state of the circuit after a manual shutdown using the SB1 "Stop" or after the device trips.

Designed SPALT(PM) can be used as one of the switching devices that are integrated into intelligent electrical networks [15-19].

\section{Conclusions}

1. The use of devices that allow dividing the power line into areas provides the necessary sensitivity to protect each section of the line as well as the ability to supply power to undamaged areas from a backup power source. When developing these devices, it is necessary to take into account the electromechanical characteristics of switching devices that are planned to be used for switching lines.

2. The use of vacuum contactors makes it possible to implement the principles of $0.38 \mathrm{kV}$ smart electric networks since they have high network switching speed, a large resource, the ability to switch short circuit currents in $0.38 \mathrm{kV}$ networks and the creation on their basis of automated switching devices installed in power lines. 


\section{References}

[1] A.V. Vinogradov, A.V. Vinogradova, Povyshenie nadezhnosti elektrosnabzheniya sel'skih potrebitelej posredstvom sekcionirovaniya $i$ rezervirovaniya linij elektroperedachi $0.38 \mathrm{kV}$ [Improving the reliability of power supply to rural consumers through partitioning and redundancy of power lines $0.38 \mathrm{kV}$ ]. (Orel, Russia: Publishing house of Orel GAU) (2016)

[2] A.V. Vinogradov, Obosnovanie primeneniya sredstv sekcionirovaniya $i$ rezervirovaniya sel'skih elektricheskih setej $0,4 \mathrm{kV}$, sovmeshchyonnyh v odnom ustrojstve [The rationale for the use of partitioning and reservation tools for rural electrical networks of $0.4 \mathrm{kV}$ combined in one device]. Actual issues of energy in agriculture (Blagoveshchensk, Russia: Publishing House of the Far Eastern State) 106-9 (2019)

[3] A. Vinogradov, A. Vasiliev, V. Bolshev, A. Vinogradova, T. Kudinova, N. Sorokin, N. Hruntovich, Methods of Reducing the Power Supply Outage Time of Rural Consumers. Renewable Energy and Power Supply Challenges for Rural Regions (Hershey, PA: IGI Global) 370-92 DOI: 10.4018/978-1-5225-9179-5.ch015 (2019)

[4] V.E. Bolshev, A.V. Vinogradov, Review of foreign sources on the application of information networks in the Smart Grid infrastructure 1(55), 8-18 (2019)

[5] S.V. Achanta, K. Hao, J. Fowler, Emerging Communications and Sensor Technologies That Advance Distribution Automation [Internet]. Avialable from: https://cdn.selinc.com/assets/Literature/Publications/Tec hnical\%20Papers/6872_EmergingCommunications_SA 20181012_Web.pdf?v=20181107-180454

[6] M. Kuzlu, M. Pipattanasomporn, S. Rahman, Communication network requirements for major smart grid applications in HAN, NAN and WAN. Computer Networks $\quad 67, \quad 74-88 . \quad$ DOI: 10.1016/j.comnet.2014.03.029 (2014)

[7] Y. Kabalci, A survey on smart metering and smart grid communication. Renewable and Sustainable Energy Reviews 57, 302-18 (2016)

[8] V.E. Bolshev, A.V. Vinogradov, Perspektivnye kommunikacionnye tekhnologii dlya avtomatizacii setej elektrosnabzheniya [Perspective communication technologies for automation of power supply networks]. Bulletin of Kazan State Energy University T.11,2(42), 65-82 (2019)

[9] A.N. Kharkhardin, Sravnitel'naya harakteristika kommutacionnyh apparatov pri razrabotke sekcioniruyushchego punkta s funkciej AVR [Comparative characteristics of switching devices in the development of a partitioning point with the function of ATS]. Proc. of the IV All-Russian Youth Scientific Conf. "Energy. Problems and development prospects" (Tambov, Russia: TSTU Publishing Center) (2019)

[10] ABB Group [Internet] [cited 2019 Jule 07]. Available from: https://new.abb.com/ru (2019)

[11] IEK Group [Internet] [cited 2019 Jule 07]. Available from: https://www.iek.ru/ (2019)
[12] Schneider Electric [Internet] [cited 2019 Jule 07]. Available from: https://www.schneiderelectric.ru/ru/ (2019)

[13] Operating manual for LSM/TEL vacuum contactor [Internet] [cited 2019 Jule 07]. Available from: http://xn--80aajzhcnfck0a.xn-p1 ai/PublicDocuments/0514866.pdf (2019)

[14] A.V. Vinogradov, Novye mul'tikontaktnye kommutacionnye sistemy $i$ postroenie na ih baze struktury intellektual'nyh raspredelitel'nyh elektricheskih setej [New multi-contact switching systems and building on their base the structure of intelligent electrical distribution networks]. Agrotechnology and energy supply 3(20), 7-20 (2018)

[15] M.T. Burr, Reliability demands drive automation investments. Public Utilities Fortnightly, Technology Corridor department. 1(11), [Internet] [cited 2018 September 19]. Available from: http://www.fortnightly.com/fortnightly/2003/11/technolo gy-corridor. (2003)

[16] Grid Modernization the Smart Grid [Internet] [cited 2019 December 10]. Available from: https://www.energy.gov/oe/activities/technologydevelopment/grid-modernization-and-smart-grid

[17] Smart Grids European Technology Platform [Internet] [cited 2019 December 10]. Available from: www.smartgrids.eu

[18] V. Kharchenko, V. Gusarov, V. Bolshev, Reliable Electricity Generation in RES-Based Microgrids. Handbook of Research on Smart Power System Operation and Control (Hershey, PA: IGI Global) 162-87 DOI: 10.4018/978-1-5225-8030-0.ch006 (2019) 